\title{
Bacteria in wooden box fermentation of cocoa in Daklak, Vietnam
}

\begin{abstract}
Bacteria play an important role in the fermentation process of the cocoa bean. For example, bacteria from the genus Acetobacter oxidize ethanol, produced by yeast, to form acetic acid. While the acetic acid is formed during the cocoa fermentation, the temperature increases due to biochemical reactions, killing germs and breaking the cell wall. Therefore, these compounds within cells had the opportunity to interact with each other to form new chemical compounds. The presence of numerous chemical compounds during fermentation enhances the color and quality of cocoa beans. Fermentation is the most important step in cocoa processing as it contributes to the flavor, color and texture characteristics of cocoa beans used in making chocolate. Morphological characterizing methods and sequence analysis of 16S rRNA genes were used in this study for identifying some bacterial species. The results show that the number of CFU ranged from $1.8 \times 10^{4}$ to $7.2 \times 10^{7} \mathrm{CFU} / \mathrm{g}$ of fresh cocoa beans. In total, 11 different colony morphologies belonging to 7 species of bacteria were isolated and identified, showing $99-100 \%$ similarity to Genbank sequences. The species include Acetobacter tropicalis, Acetobacter pasteurianus, Acetobacter indonesiensis, Acinetobacter calcoaceticus, Microbacterium oxydans, Sphingomonas melonis, and Serratia marcescens.
\end{abstract}

Keywords: Acetobacter, Cocoa, Fermentation, Identification, Pulp
Volume 5 Issue 7 - 2017

\author{
Phan Thanh Binh, Nguyen Viet Tru, Vo Thi \\ Thuy Dung, Nguyen Thi Thoa, Pham Van \\ Thao, Tran Thi Tham Ha,Vo Van Thang \\ The Western Highland Agriculture and Forestry Science \\ Institute, Vietnam
}

Correspondence: Phan Thanh Binh, The Western Highland Agriculture and Forestry Science Institute, Buonmethuot, Daklak, Vietnam, Tel 8405003862845 , Email binhanphuochanh@gmail.com

Received: October 26, 2017| Published: December 06, 2017

\section{Introduction}

There are five main groups of microorganisms that participate in fermenting cocoa:filamentous fungi, yeasts, lactic acid bacteria, acetic acid bacteria, and various Bacillus species. ${ }^{1}$ Fungi, yeasts, lactic acid bacteria, and acetic acid bacteria are active mainly in the first stage (from 0 to $48 \mathrm{~h}$ ). Yeasts convert sugar from the mucilage of cocoa beans into alcohol, and break the pectin down into pectinic acid, which enhances the quality of the cocoa beans. ${ }^{2}$ Acetobacter pasteuriansis, a spontaneous bacterial species, plays a significant role in the cocoa bean fermentation process by oxidizing ethanol into acetic acid. They are capable of tolerating high ethanol levels and high temperatures, and thrive in the presence of calcium lactate and mannitol. ${ }^{3}$ There is a high density of acetic acid bacteria (A. syzygii, A. pasteurianus and A. tropicalis) present during the fermentation process. ${ }^{4}$ After stage 1 (from $48 \mathrm{~h}$ to $72 \mathrm{~h}$ ), Bacillus species form, which kill the germ and break the tissue wall, and this allows for many reactions resulting in the formation of chocolate flavors and color of the cocoa bean. The current study employs molecular biotechnology to isolate and identify the bacterial species that ferment the cocoa bean in the Daklak province. This knowledge has, in turn, allowed the researchers to further explore the facts involving the fermentation process and the production of high quality cocoa beans in Vietnam.

\section{Materials and methods}

\section{Materials}

Experimental material:Cocoa pods (Forastero and Trinitario varieties) were provided by Eakmat company, Buon Ma Thuot City, Daklak province, seasonal crop 2011-2012.

Media for isolating microbial: ${ }^{1}$ Yeast Extract Glucose Chloramphenicol (YGC) Agar including glucose 50g/l (Merk), yeast extract 10g/l (Merk), CaCO3 30g/l (Merk), agar 20g/l, 0.1\% cycloheximide, $50 \mathrm{mg} / \mathrm{l}$ penicillin (Sigma), $\mathrm{pH}=5.6$. Bacteria were nurtured in media in a culture box with constant temperature $\left(25^{\circ} \mathrm{C}\right)$ over a period of 5 to 8 days in order to observe morphology and motility. ${ }^{4}$ Liquid $\mathrm{YGC}$ media was incubated at $25{ }^{\circ} \mathrm{C}$ for 3 to 4 days prior to introduction of bacteria.

Gram staining:Application of dual staining method invented by Christian Gram.

\section{Methods}

Isolating bacteria from cocoa annealing mass:The pods were opened and fresh beans were collected by hand. The fermentation was carried out in a wooden box. During the 6-day fermentation period, the turning process was conducted twice daily and the samples were collected every day from 5 points ( 4 corners and 1 center) at $10 \mathrm{~cm}$ from the surface, and approximately $200 \mathrm{~g}$ of bean per sample was collected for further analyses. The pulp of the bean was separated, ground, and mixed. This mixture was diluted and cultured on isolation medium at $25^{\circ} \mathrm{C}$ for 2 to 8 days. Colony counting was performed and the density of acetic acid bacteria (VA) was determined.

Bacterial pure culture:Microorganisms were cultured on YGC agar medium at a of $\mathrm{pH} 5.6$, at $25^{\circ} \mathrm{C}$. The typical micro-colonies were selected and transferred to sterilized $\mathrm{NaCl}$ solution to make a suspension, then cultured on solid medium (YGC Agar) to favor the bacteria growth.

Observation of morphological characteristics: Observed motility of bacteria using the Hanging Drop method. The bacteria were stained according to Christian Gram method and visualized by Optika B-350 electron microscope at $100 \mathrm{X}$.

Examination of physiological characteristics:Morphology, surface, cutting face and colors of the colony of different lines which were purely cultured. ${ }^{5}$

DNA analysis and identification of the bacteria: $1.5 \mathrm{ml}$ of bacteria solution purely cultured on YGC agar media was centrifuged at 10,000 rpm for 2 minutes. The pellets were collected, while the supernatant 
was discarded. These pellets were transferred into a tube of lysis buffer $(567 \mu \mathrm{l}$ TE buffer (Tris-HCl $10 \mathrm{mM}$, EDTA $1 \mathrm{mM})$ with $30 \mu \mathrm{l}$ of $10 \%$ sodium dodecyl sulfate (SDS), $3 \mu 1$ proteinase $\mathrm{K} 20 \mathrm{mg} / \mathrm{ml}$ ), and annealed for an hour at $37^{\circ} \mathrm{C}$ for. After annealing, $100 \mu \mathrm{NaCl}$ $5 \mathrm{M}$ and $80 \mu \mathrm{CTAB} / \mathrm{NaCl}$ were added, well-mixed, and continuously annealed for 10 minutes at $65^{\circ} \mathrm{C}$. After that, $1 \mathrm{ml}$ of chloroform/ isoamyl alcohol was added, blended, and centrifuged for 4-5 minutes $(10,000 \mathrm{rpm})$. The supernatant solution was transferred to another clean tube followed by the addition of sufficient amount of phenol/ chloroform/isoamyl alcohol, mixed and centrifuged for 5 minutes. Next, $0.6 \mathrm{ml}$ isopropanol was added to the supernatant in the tube and centrifuged, and the supernatant was discarded. This was followed by the addition of $1 \mathrm{ml} 70 \%$ ethanol to dissolve the pellets. The bacterial DNA was precipitated out when this mixture was centrifuged for 5 minutes and dried in a dry heat incubator for annealing to occur. DNA concentration was calculated by using a Bio Photometer machine. 5 $\mu 1$ of sample was transferred into PCR tubes, and the reaction was performed to amplify the $16 \mathrm{~S}$ intergenic spacer of bacterial rDNA by PCR Thermal Cycler system. Visualization of amplified DNA was performed by electrophoresis using $2 \%$ agarose and the bands of the amplified DNA were recorded by Gel Doc machine. PCR products were purified using QIA quick PCR Purification Kit from QIAGEN. The sequencing was performed using ABI 3130XL, and analysis of DNA sequencing reaction was performed on sequencing analysis 5.3 software (Applied Biosystems, USA, 2007), and was compared with the GenBank database (at Nam Khoa BIOTEK Laboratory - ISO 15189).

\section{Results and discussion}

The results of identifying bacterial density in fermented cocoa samples

The results of microbial identification revealed fluctuations in bacterial density, which predominated at 24 hours, 48 hours, and 72 hours with maximum populations of $7,2 \times 10^{7} \mathrm{CFU} / \mathrm{g}$ at 72 hours. There was a gradual decrease towards the end of the fermentation process. A low colony density at some stages of fermentation ( 0 hour, 120 hours and 144 hours) ranged from $1,8 \times 10^{3}$ to $5,9 \times 10^{4} \mathrm{CFU} / \mathrm{g}$
(Table 1). The measurements were higher at 24 hours, 48 hours and 72 hours (after the start of fermentation) because of water running out from the cocoa mass during fermentation, which contributed to the ventilation of the annealing mass that provided a more suitable condition for bacterial growth.

\section{Identification of bacterial morphological characteristics}

In this study, we have isolated 11 different bacterial types that differ in colony morphological characteristics including shape, surface, color, and cross-section. These findings showed that the majority of colonies were round, wet, white, light brown and light yellow. In addition, some shapes were wrinkle and saw tooth surround (Table 2).

The above-mentioned characteristics differentiated the colonies from one another. However, some of them were not clearly distinguished, as they were similar to each other in shape and colony traits. (e.g. ATD6 and ATD7; ATD3 and ATD4, etc.). They are likely to have a similar origin. Most cells from colonies were Gram-negative, circular/ellipse or rod-shaped, and clustered or non-clustered. These cells were unable to move or rarely moving. Identification based on morphology was difficult as some bacteria were quite similar (Table 3 , Figure 1).

\section{Results of identifying name of species based on molecular biotechnology}

In the current study, 7 different bacterial species were identified based on their similarity of sequences with those in Genbank (99-100\%) 3 species (Acetobacter tropicalis, Acetobacter pasteurianus, Acetobacter indonesiensis) were capable of metabolizing ethanol and mannitol into acetic acid, catalyzing the hydrolysis to form $\mathrm{CO}_{2}$ and $\mathrm{H}_{2} \mathrm{O}$. Another species, Acinetobacter calcoaceticus rarely appeared in the cocoa fermentation. Also, there is no literature evidence to validate the roles of Microbacterium oxydans, Sphingomonas melonis, or Serratia marcescens in the fermentation process. However, they could change ethanol to acetic acid, based on different substrates that were not cocoa pulp. Serratia marcescens is able to produce lipase for fatty acid hydrolysis, which cause the rancidity (Table 4).

Table I Temperature, $\mathrm{pH}$ and VA density in cocoa beans during fermentation

\begin{tabular}{lllll}
\hline Time (Hour) & Mass Temperature $\left({ }^{\circ} \mathbf{C}\right)$ & $\mathbf{p H}-$ Pulp & $\mathbf{p H}-$ Cotyledon & CFU/g Fresh Bean $\left(\mathbf{x I 0 ^ { 7 } )}\right.$ \\
\hline 0 & 22.6 & 3.96 & 6.99 & 0.0018 \\
24 & 40.1 & 3.49 & 6.59 & 4.744 \\
48 & 41.7 & 3.5 & 6.38 & 2.6333 \\
72 & 45.9 & 3.61 & 5.75 & 7.2 \\
96 & 41.9 & 3.86 & 5.73 & 0.17 \\
120 & 43.7 & 4.15 & 5.07 & 0.0433 \\
144 & 40.9 & 4.29 & 5.13 & 0.0588 \\
\hline
\end{tabular}

Table 2 Bacterial morphological characteristics (colonies)

\begin{tabular}{llllll}
\hline No. & Name of colonies & Shapes & Surface & Face & Color \\
\hline I & ATDI & Round, regular & Glossy wet & flat & opaque white \\
2 & ATD2 & Round, regular, rims & Glossy wet & flat & opaque white \\
3 & ATD3 & Round, regular & Glossy wet & ripple & opaque white \\
4 & ATD4 & Round, regular & Glossy wet & ripple & opaque white \\
5 & ATD5 & Round, regular, sawtooth & Glossy wet & flat & Dark pink \\
6 & ATD6 & Round, regular & fairly wrinkle, wet & ripple & opaque white \\
7 & ATD7 & Round, regular & fairly wrinkle, wet & ripple & opaque white \\
8 & ATDI2 & Round, regular & Glossy wet & flat & opaque white \\
9 & ATDI7 & Round, regular & Glossy wet & flat & white \\
I0 & ATDI8 & Round, regular & Glossy wet & flat & opaque white \\
II & ATD22 & Round, regular & Glossy wet & flat & opaque white \\
\hline
\end{tabular}


Table 3 The morphological characteristics of colony cells

\begin{tabular}{lll}
\hline No. & Name & Morphological Characteristics \\
\hline I & ATDI & Gram-negative, particle shape (ellipse), cells into pairs, cell groups or the single cell. \\
2 & ATD2 & Gram-negative, particle shape (ellipse), cells into pairs, cell groups or the single cell. \\
3 & ATD3 & Gram-negative, particle shape, comma-shape, cells into clusters or the single cell. \\
4 & ATD4 & Gram-negative, particle shape, cells into clusters or the single cell. \\
5 & ATD5 & Gram-negative, short rod-shaped, long rod-shaped, cells into clusters or the single cell. \\
6 & ATD6 & Gram-negative, particle shape, cells into pairs, cell groups or the single cell. \\
7 & ATD7 & Gram-negative, particle shape (ellipse), cells into pairs, cell groups or the single cell and cannot move. \\
8 & ATDI2 & Gram-negative, circle shape, cell groups or the single cell. \\
9 & ATDI7 & Gram-negative, ellipse, cells into pairs or groups. \\
I0 & ATDI8 & Gram-negative, particle shape, cells into pairs or the single cell. \\
II & ATD22 & Gram-negative, ellipse, cells into pairs, cell groups or the single cell. \\
\hline
\end{tabular}

Table 4 I6S-rRNA sequences and comparison results with Genebank of bacterial strains

\begin{tabular}{lllll}
\hline No. & Name & Identification by DNA & Similarity (\%) & References \\
\hline I & ATDI & Acinetobacter calcoaceticus & $99-100$ & 6 \\
2 & ATD2 & Acetobacter tropicalis & 100 & 2,7 \\
3 & ATD3 & Acetobacter tropicalis & 99 & $3,8,9$ \\
4 & ATD4 & Serratia marcescens & 100 & 3 \\
5 & ATD5 & Acetobacter pasteurianus & 100 & $3,8,9$ \\
6 & ATD6 & Acinetobacter calcoaceticus & 100 & $3,8,9$ \\
7 & ATD7 & Sphingomonas melonis & 100 & 10 \\
8 & ATDI2 & Acetobacter pasteurianus & 100 & 2,7 \\
9 & ATDI7 & Acetobacter indonesiensis & $99-100$ & 2,7 \\
I0 & ATDI8 & Microbacterium oxydans & 100 & 8 \\
II & ATD22 & Acetobacter pasteurianus & 100 & $3,8,9$ \\
\hline
\end{tabular}

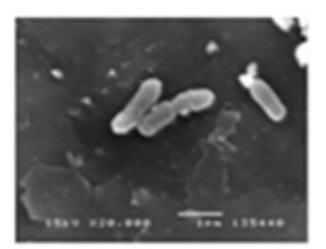

Acinete, calceaceticus (ATD1)

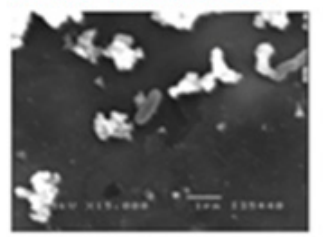

Sercotia marcescens (ATD4)



Sphineomenas melonis (ATD7)


Microbacterium oxodans(ATD18) A. pasteuciamus(ATD22)

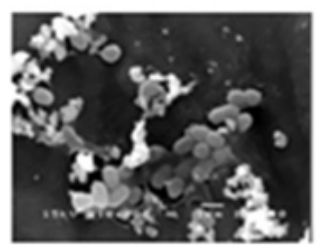

A. tropicalis(ATD2)

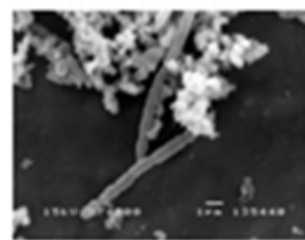

A. pastencianus(ATD5)

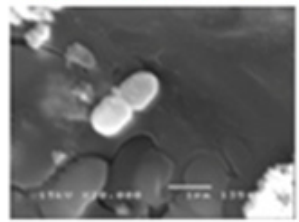

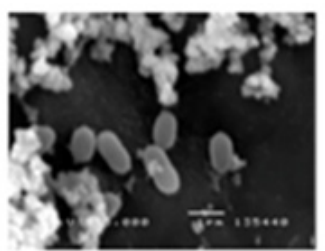

A. tropicalis(ATD3)

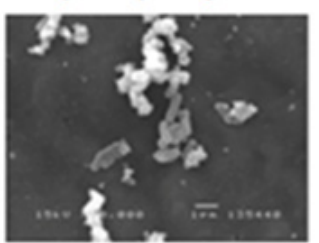

Acinete, calceaceticus (A TD6)



A. indoneriensis(ATD17)

Figure I Bacterial strains. 
ATD2 and ATD3 were identified belonging to $A$. Tropicalis strains; forms of ATD5, ATD12, ATD22 belonged to A. pasteurianus strains and ATD17 was a member of $A$. indonesiensis. These bacterial species appeared regularly in the cocoa bean mass from some countries producing cocoa (Indonesia, Thailand, Philipines, and Ghana). Their density and frequency of occurrence were quite high in the annealing mass of cocoa bean. Furthermore, they also play a crucial role in the biochemical reactions that produce the chocolate flavor precursors. Three of the above-mentioned eleven forms, including Microbacterium oxydans, Sphingomonas melonis, Serratia marcescens are lacking in research about their effects in cocoa fermentation.

\section{Conclusion}

Bacterial density significantly ranged from $0.18 \times 10^{5}$ to $7.2 \times 10^{7}$ CFU/gram and reached the highest point at 72 hours. There were seven different species which comprised of Acetobacter tropicalis, Acetobacter pasteurianus, Acetobacter indonesiensis, Acinetobacter calcoaceticus, Microbacterium oxydans, Sphingomonas melonis, and Serratia marcescens. Three of them have not been mentioned in any previously published papers including Microbacterium oxydans, Sphingomonas melonis, Serratia marcescens which exhbited a similarity of up to $99-100 \%$ in comparison with those of Genbank.

\section{Acknowledgements}

None.

\section{Conflicts of interest}

None.

\section{References}

1. Ardhana MM, Fleet HG. The microbial ecology of cocoa bean fermentations in Indonesia. Int J Food Microbiol. 2003;86(1-2):87-99.
2. Nicholas Camu, Tom De Winter, Kristof Verbrugghe, et al. Dynamics and biodiversity of populations of lactic acid bacteria and acetic acid bacteria involved in spontaneous heap fermentation of cocoa beans in Ghana. Appl Environ Microbiol. 2007;73(6):1809-1824.

3. Luc De Vuyst, Nicholas Camu, Tom De Winter, et al. Validation of the (GTG)-rep-PCR fingerprinting technique for rapid classification and identification of acetic acid bacteria, with a focus on isolates from Ghanaian fermented cocoa beans. Int $J$ Food Microbiol. 2008;125(1):79-90.

4. Nielsen DS, Teniola OD, Ban-Koffi L, etal. The microbiology of Ghanaian cocoa fermentations analysed using culture-dependent and cultureindependent methods. Int J Food Microbiol. 2007;114(2):168-186.

5. Ilse Cleenwerck, Angel Gonzalez, Nicholas Camu, et al. Acetobacter fabarum $s p$. nov., an acetic acid bacterium from a Ghanaian cocoa bean heap fermentation. Int J Syst Evol Microbiol. 2008;58(pt 9):2180-2185.

6. George V, H Hui G. Applied mycology and biotechnology for agriculture and foods. Applied Mycology and Biotechnology 1:1-11.

7. Schwan RF, Wheals AE. The microbiology of cocoa fermentation and its rule in chocolate quality. Crit Rev Food Sci Nutr. 2004;44(4):205-221.

8. Garcia AT, Papalexandratou Z, Hendryckx H, et al. Diversity of the total bacterial community associated with Ghanaian and Brazilian cocoa bean fermentation samples as revealed by a $16 \mathrm{~S}$ rRNA gene clone library. Appl Microbiol Biotechnol. 2010;87(6):2281-2292.

9. Romero Cortes T, Robles Olvera V, Rodriguez-Jimenes G. Isolation and characterization of acetic acid bacteria in cocoa fermentation. Afr $J$ Microbiol Res. 2011;6(2):339-347.

10. Buonaurio R, Stravato VM, Kosako Y, et al. Sphingomonas melonis sp. nov., a novel pathogen that causes brown spots on yellow Spanish melon fruits. Int J Syst Evol Microbiol. 2002;52(pt 6):2081-2087. 